\title{
A Pollution Offset System for Trading Non-point Source Water Pollution Permits
}

Ranga Prabodanie, R.A., Raffensperger, J.F., Milke, M.W., Read, G.

Accepted for publication in Environmental and Resource Economics, September 2009

\begin{abstract}
Water pollution from non-point sources is a global environmental concern.

Economists propose tradable permit systems as a solution, but they are difficult to implement due to the nature of non-point sources. We present a pollution offset system for trading non-point source water pollution permits. Conventional pollution offset systems suffer from thin markets and transaction costs. In this paper, we show how to overcome these problems with a centrally managed common-pool market. We define permits as allowable nitrate loading to a groundwater aquifer. This trading system utilizes estimates of potential nitrate leaching from land uses, a set of transport coefficients generated from a simulation of nitrate transport in groundwater, an online trading system, and a linear program to clear the market. We illustrate the concept using a hypothetical case study.
\end{abstract}

Key words: nitrate, non-point sources, operations research, trading, water pollution permits

This paper has not been submitted elsewhere in identical or similar form, nor will it be during the first three months after its submission to the publisher. 


\section{Introduction}

A hundred years ago, the main sources of water pollution were untreated human wastes and industrial discharges. Industrialized nations now control these point sources through treatment and disposal technologies, and pollution laws (Revenga \& Mock, 2000). Nevertheless, even the developed world suffers from non-point (diffuse source) pollution caused mainly by intensive agriculture.

Nitrate is a major agricultural non-point source pollutant. Synthetic fertilizer, manure, and livestock effluents contain nitrogen in different forms as nitrate, ammonia, ammonium, urea, amines, or proteins. Once applied on soil, nitrogen may be taken up by plants, carried away by surface runoff, or transformed into nitrate and leach into groundwater. Nitrogen loading into water bodies usually occurs as nitrate leaching into the groundwater system rather than as surface runoff. Excess nitrates in water can cause severe threats to human health and aquatic ecosystems.

National and international environmental authorities have set water quality standards (or maximum acceptable levels of pollution) to meet human and ecosystem health needs. New Zealand's national drinking water guideline for nitrate is $50 \mathrm{mg} / \mathrm{l}$. In New Zealand's Waikato region, groundwater nitrate levels commonly exceed this level due to intensive market gardening and livestock farming (Environment Waikato, 2008). In the United States, most shallow groundwater aquifers in agricultural areas have high nitrate concentrations (U. S. Geological Survey, 1999).

Tradable permit systems have been proposed as a means of controlling water pollution from commercial sources such as dairies and crop farms. The main benefits of trading systems are the ability to reveal the economic values of the discharge rights and to shift them from low value uses to high value uses. For commercial land users, tradable pollution permit systems provide additional flexibility in land use decisions.

However, defining, pricing and trading of non-point source water pollution permits require measurement of pollutant leaching and runoff losses from the soil and tracing 
of fate of pollutants in groundwater. The pollutant flow paths, attenuation during the flow, and time lags between the discharge and appearance at a water body depend on catchment hydrogeology and climate. Different sources affect a given receptor (a water body or a point on a water body where water quality is monitored) with different intensities and timings, so one-to-one bilateral trade can worsen water quality at some receptors. The key requirement to facilitate trade in non-point source water pollution permits is the ability to relate the source loading to the time varying impacts on water quality of hydro-geologically connected water bodies at different receptors (Morgan, Coggins, \& Eidman, 2000; O'Shea, 2002). Hence, a non-point source water pollution trading system needs hydrological modelling and a central authority to facilitate and oversee trading. The central authority also needs a welldefined methodology to determine the equilibrium prices and allocations.

This paper is specifically about nitrate leaching into groundwater. The term "nitrate permit" will refer to a water pollution permit, which allows a specified amount of nitrate leaching (loading) into a groundwater aquifer. We use hydrological simulations to obtain a set of coefficients which describe the relationships between the source loading and quality deterioration at receptors.

We propose a new pollution-offset type trading system to be implemented as a centrally controlled online market, where traders buy from and sell to a common pool, rather than trade pair-wise. Users submit bids and offers to an online trading system overseen by a market manager. The market manager uses a linear program to clear the market (i.e., to determine the prices and net purchases or sales). The linear program ensures that water quality standards are met all times and maximum benefit is achieved. To demonstrate the proposed trading system, we apply it to a simple case study. We conclude with a discussion on how our trading system overcomes the problems in conventional pollution offset systems to suit for trading non-point source water pollution permits. 


\section{Pollution Permit Trading: Theory and Application to Water Pollution}

Coase (1960) was the first to propose a market mechanism as a means of dealing with economic externalities. Dales (1968) demonstrated the applicability of trading solutions to the specific problem of water pollution. Montgomery (1972) provided the theoretical foundation for trading pollution permits, introducing "diffusion coefficients" to relate source emissions to receptor pollutant concentrations. Montgomery discussed an "ambient" permit system in which an authority issues permits for each receptor separately. Sources must maintain a portfolio of permits to match impacts on each receptor. Montgomery's system suffered from high transaction costs, so Krupnick, Oates, and Verg (1983) proposed a pollution offset system. A pollution offset system needs an environmental quality model to simulate the impact of each proposed transaction and ensure that it does not cause quality standards to be violated at any receptor. McGartlend and Oates (1985) presented a modified offset system by introducing redefined quality standards to the original offset system. McGartlend (1988) argued that the ambient permit and pollution offset systems are equivalent under perfect competition, and a competitive equilibrium exists, but there are obstacles in reaching this equilibrium. He suggested that brokers could help overcome these obstacles. Brokering was further developed by Ermoliev, Michalevich, and Nentjes (2000), who identified the need for multilateral trade in pollution permits. They suggested that an environmental agency, acting as a Walrasian auctioneer, could coordinate the trade among decentralized agents submitting bids and offers online.

Though much of the economic theory appears to be established, actual water pollution permit trading is mostly limited to a few point source trades (King and Kuch, 2003). The literature is dominated by point source emission or ambient permit trading systems (Neil, David, Moore, \& Joeres, 1983; Eheart, Brill, Lence, Kilgore, \& Uber, 1987; Leston, 1992; Weber, 2000; Hung \& Shaw, 2005). We discuss three types of 
non-point source discharge permits trading system proposed to date: an ambient permit system, a trading ratio system and a zonal permit system.

Morgan, Coggins, and Eidman (2000) seem to be the first to present a method for trading non-point source permits. They propose an ambient permit system for trading nitrate discharge permits. It consists of three parts: (1) a production model that estimates the profits from different production practices (crop rotation and fertilizer application rate), (2) a soil model that estimates the water and nitrogen leaching from each practice, and (3) a groundwater model that simulates the nitrate movement in groundwater. An auctioneer finds a price for each receptor which satisfies the water quality standards and balances demand and supply. This system is best suited when there is only one receptor, as a separate auction is needed for each receptor. Even for one receptor, a large number of auction rounds may be needed to clear the market.

Horan, Shortle, and Abler (2002) designed a system for trading nitrogen permits, including point and non-point sources. A trade between two source categories is based on a trading ratio, determined so that pollution does not increase because of trade. The model does not include explicit water quality standards, but rather an economic cost of pollution. Thus, their system requires knowledge of the cost of pollution to the rest of society, and has no constraints associated with the sustainability of the environment.

Lock and Kerr (2007) and Kerr, Rutherford, and Lock (2007) present a non-point source nutrient discharge permit trading system for a catchment which drains to a lake. The relationship between discharge and input to the receptor is handled by a zonal permits system. Zones are distinguished by the years between discharge and input to the lake, and permits are defined based on the year in which input to the lake can occur. This system also creates several markets for different permit types. The maximum acceptable load into the lake in the input year determines the total number of permits of a given type. Therefore, one-to-one bilateral trade is possible for each type of permit. This zonal permit system is applicable only when there is a single receptor point. 
Ambient permit systems suffer from high transaction costs due to maintaining a portfolio of permits and having several markets (Ermoliev et al., 2000). They usually work well with one or few receptors. Even with a single receptor, non-point sources usually have impacts over different time scales. Consequently, different types of permits must be defined in terms of the time of impact. These temporal impacts again create many markets. If the impacts last for more than one time step, a source may need a portfolio of permits to cover operation in a single year. Hence, there are significant difficulties in starting and operating ambient permit systems for non-point source pollution, and simplifications can lead to undesirable impacts on water quality.

The outcomes of trading ratio systems depend on how the administrator selects the trading ratios, and no proven method exists to find the right trading ratios for nonpoint source trading systems. On the other hand, zonal permit systems are hard to apply to catchments with many receptors. When zones are defined in terms of only one parameter, for example lag time, other factors such as spatial variation in attenuation may not allow the trading system to achieve all potential benefits of trade.

As our literature survey reveals, none of the prior work has attempted a pollution offset system for trading non-point source water pollution permits, possibly due to the need for environmental simulations and the understandable fear of thin trading from high transaction costs. We propose a pollution offset system, supported by hydrological, economic and optimisation models, with the potential to overcome those issues.

\section{Methodologies: Designing a Pollution Offset System}

The proposed nitrate permit trading system is a type of pollution offset system, applicable at the catchment scale. It consists of four components. First, a leaching loss model estimates nitrate leaching to the aquifer from potential land uses and thus the size of the permit required for each land use option. Based on permit requirements and profitability of land use options, land users choose their individual demand and 
supply relative to an initial allocation of permits. Second, a contaminant transport model provides a matrix of transport coefficients which quantify the relationship between source loading and pollution effect at the receptors. Third, a centrally controlled electronic market facilitates trade by accepting bids and offers from land users. Fourth, a linear program determines the optimal trades based on the sourcereceptor relationships and land user demand and supply. Below, we provide a detailed description of each component and its contribution.

\subsection{Leaching Loss Model}

With the first component, we estimate the nitrate loading to the aquifer from possible land use options. A land use option is a combination of factors such as type of crop or stock; stocking density; timing, method and rate of fertilizer application; and other land management practices. The size of the nitrate permit required to adopt a certain land use option at a site is the estimated nitrate leaching from that land use option, at that site. Hence, the permit size determines maximum allowable leaching. These permits are suitable when impacts are mostly due to leaching, and surface runoff is negligible. Otherwise, a separate type of permit should be defined for runoff.

A regional environmental authority acts as a facilitator of trade. We assume that the authority can identify the potential land use options, and can estimate nitrate leaching from each option. In New Zealand, most environmental authorities have tools (e.g., Overseer, FarmSIM, and NPLAS) to estimate leaching. If those tools were available to the users, they could estimate the leaching from intended operations themselves. In any case, a single official estimate is needed for the market.

Nitrate leaching, and therefore the nitrate permits, can be specified in two equivalent ways.

Mass nitrate leaching to the aquifer below the land area, as mass leaching per land area per period, $\mathrm{kg} / \mathrm{ha} /$ year. 
Nitrate concentration of the water leaching to the aquifer (recharge) from the land area, $\mathrm{mg} / \mathrm{l}$.

In this paper, we use the first method and specify the permits in $\mathrm{kg} / \mathrm{ha} / \mathrm{year}$, but the difference is only a change of units.

\subsection{Nitrate Transport Model}

In the second component, we establish the numerical relationship between source loading and level of water pollution at each receptor, represented by a matrix of transport coefficients. The transport coefficients are synonymous with the diffusion coefficients discussed in the prior work on both air and water quality trading systems, with one key difference: coefficients used previously had only two indices, source and receptor, but the transport coefficients used here have a third dimension of time. The transport coefficients may be defined in several equivalent ways.

The concentration at a receptor, at a given time, from one unit of leaching at a pollution source during a certain time period (measured in concentration units, e.g., $\mathrm{mg} / \mathrm{l}$, and used with receptors such as groundwater wells).

The mass pollutant flux at a receptor, at a given time, from one unit leaching at a pollution source during a certain time period (measured in flux units, e.g., kg/day, and used with receptors such as streams).

The mass pollutant input to a receptor during a given time period, from one unit leaching at a pollution source during a certain time period (measured in mass units, e.g., $\mathrm{kg}$, and used with receptors such as lakes).

To estimate the transport coefficients, we simulate the contaminant transport based on the hydro-geological properties of the catchment, using commonly available computer codes. Some software tools used to simulate groundwater flow and contaminant mobility in groundwater are MODFLOW (Harbaugh, Banta, Hill, \& McDonald, 2000), MT3D (Zheng, 1990) and MODFLOW GWT (U. S. Geological Survey, 2006). 
The simulations treat leaching as contaminated recharge, and quantify source loading as the pollutant leaching into the model cells (zone) which represent the aquifer below the source (e.g., farm). We can therefore simulate unit leaching from each source $i$ to obtain its impact on the concentration, flux or mass at each receptor $j$, at each time step $t$ of interest. Each of these values fills an entry $[i, j, t]$ of the transport coefficient matrix.

Other sources of nitrate such as urban drainage and rainwater and public septic systems may not be not considered as tradable. However, these non-tradable sources have impacts on trading, so we have to estimate their contribution at each receptor. We can simulate the non-tradable sources using the same contaminant transport model and obtain the concentration, flux or mass that occurs at each receptor, at each time step of interest. These non-tradable source contributions and the water quality standards together determine the availability of nitrate permits to be distributed via trading.

\subsection{The Online Trading System}

The third component to our system is a centrally controlled online trading system which brings buyers and sellers together and facilitates multilateral trade. Initial permits are allocated to land users, who are then allowed to trade through a web interface. Traders do not trade with each other pair-wise, but rather buy from and sell to the centrally-controlled market. We suggest that a regional environmental authority is the best candidate to oversee the trading system. We call the person or the institution who oversees the market as the "market manager."

Each user calculates their demand or supply at each possible permit price, based on the potential profit from each land use option and the cost or revenue from buying or selling the nitrate permits required for each land use option. Then users submit bids and offers to the online trading system as a series of price and quantity (buy or sell) pairs. These bids and offers define every user's demand function for nitrate permits. 
Clearing the market is complicated by many factors. First, users are bidding for permits that have different impacts on the water quality constraints concerned. Therefore, the bids are not comparable between traders. Second, the usual criteria of accepting the highest bids and lowest offers is not applicable in this case because the acceptance of the highest bid may violate the water quality standards. Instead, to clear the market, the market manager must find a (potentially different) price for every source, so that demand matches hydrology-adjusted supply, quality meets requirements at all receptors at all times, and social benefit achieves the maximum. As a means of dealing with the complexity, we use a linear program to clear the market. Linear programs have been successfully used for this purpose in complicated multilateral trading situations such as electricity markets (Hogan, Read, \& Ring, 1996). We give the linear program below in section 3.4.

The market manager runs the linear program and displays the calculated allocations and prices on the trading system web. A few tentative rounds of market clearance may be helpful for the participants to generate expectations about the results and finalise the bids. Once the market is officially cleared (final clearance), the market manager collects money from sellers, pays the buyers, and clears the market. Buyers pay and sellers receive a specific price assigned to each. There is no matching of buyers and sellers, as everyone trade through a common pool. The prices need not match, and total purchases need not to equal total sales, as the permits are not directly comparable.

The online trading system should authenticate users at login and accept bids and offers. Access to information should be customised, so that everyone can view public information like trade history and prices, but not private information such as other trader's pending bids. Bids and offers can be stored in a database, along with other relevant information such as land user's details and initial allocations. The market manager should have administrative rights and be capable of running the linear program and determining the optimal feasible trades. 


\subsection{Linear Program}

The final component in our trading system is the linear program, which will determine the prices and allocations that maximise total consumer and producer surplus, subject to water quality standards and initial permit allocations.

Consumer and producer surplus, or more exactly buyer and seller surplus in this case (since no-one "consumes" pollution), measure the benefit that buyers and sellers derive from participating in a market. Maximum social benefit is achieved when the sum of buyer and seller surplus is maximised, assuming that participants have submitted truthful bids. We calculate the buyer and seller surplus from the bids and offers submitted by the traders.

We assume that permits are short term property leases rather than long term property ownership rights. Though a permit is valid for a short period, the effects exist for longer periods. Trades are feasible if water quality standards are expected to be met while the permits are valid and in the future following expiration. Hence, the planning horizon should be long enough to capture the impacts of all sources on all receptors. We divide the planning horizon into steps and impose water quality standards at every step. The length of each time step should be short enough to guarantee that the quality standards are met continuously and long enough to avoid a large number of redundant water quality constraints in the linear program.

To convert the water quality requirements into mathematical constraints, we assume a linear relationship between leaching and the quality deterioration at each receptor at every time step. By assuming linearity, we can calculate the nitrate concentration, flux or mass at any receptor as the sum of contributions from all sources. This is a commonly applied assumption in solving groundwater management problems (Morgan \& Everett, 2005).

Indices

$i=1, \ldots, N$ traders.

$j=1, \ldots, M$ receptors. 
$t=1, \ldots, T$ time periods. $t=1$ indicates the current period. The planning horizon is $T$ periods, meaning water quality constraints apply for $t=1, \ldots, T$ periods. The permits are valid only for for $t=1, \ldots, t^{\prime}$ periods $\left(t^{\prime}<T\right)$.

$k=1, \ldots, K$ bids or offer steps. Each trader can submit up to $K$ bid or offer steps.

\section{Parameters}

$A_{i}=$ initial allocation to trader $i$.

$H_{i j t}=$ the concentration, flux or mass that occurs at receptor $j$, at time $t$, from one unit leaching at pollution source $i$, during $t=1, \ldots, t^{\prime}$ (nitrate permits are valid during $t=$ $\left.1, \ldots t^{\prime}<T\right)$.

$C_{j t}=$ the total concentration, flux or mass at receptor $j$, at time $t$, from all non-tradable sources.

$S_{j t}=$ the maximum acceptable concentration, flux or mass at receptor $j$ at time $t$.

$U_{i k}=$ upper bound on $k^{\text {th }}$ bid step placed by trader $i$ (positive for buy steps and negative for sell steps).

$P_{i k}=$ price of $k^{\text {th }}$ step placed by trader $i$.

\section{Decision variables}

$b_{i k}=$ purchases/sales by trader $i$ from $k^{\text {th }}$ bid/offer.

$q_{i}=$ maximum leaching allowed for trader $i$ during $t=1, \ldots, t$. This is the size of the permit held by trader $i$ after market clearing.

$\mu_{i}=$ price of unit permit for trader $i$. This is the shadow price of constraint 2 below .

\section{Objective function}

Maximise $\sum_{i} \sum_{k} P_{i k} b_{i k}$, subject to

Upper bounds on bids and offers

If $U_{i k} \geq 0,0 \leq b_{i k} \leq U_{i k}$, else $U_{i k} \leq b_{i k} \leq 0 \quad$ for all $i=1, \ldots, N$ and $k=1, \ldots, K(1) \vartheta_{i k}$

\section{Compliance constraints}

$q_{i}-\sum_{k} b_{i k}=A_{i}$

for all $i=1, \ldots, N$

(2) $\mu_{i}$ 
Water quality constraints

$\sum_{i} H_{i j t} q_{i} \leq S_{j t}-C_{j t}$

for all $j=1, \ldots, M$ and $t=1, \ldots, T(3) \lambda_{j t}$

\section{Other constraints}

$q_{i} \geq 0$

for all $i=1, \ldots, N$

(4) $b_{i}$

The right-hand side of each water quality constraint, $S_{j t}-C_{j t}$ indicates the net amount of pollution capacity at receptor $j$ in period $t$, available for allocation through trading. We can estimate expected values for $C_{j t}$ using the same transport simulation model discussed above. However, determining $S_{j t}$ should be done carefully. Water quality standards usually specify the maximum acceptable mass pollutant discharge into a water body during a period or the maximum acceptable concentration at a time. If we set $S_{j t}$ equal to those standards, and some constraint for year $t_{0}$ becomes binding in the solution, we may not be able to allocate any permit that affects period $t_{0}$ in the future. We are currently studying the optimal method to determine $S_{j t}$ which is a problem of resource allocation over time. In this work, we assume that $S_{j t}-C_{j t}$ is given by the catchment authority, as the total amount of resource available for allocation via trading.

The variables listed in the right hand side of the constraints, $\vartheta_{i k}, \mu_{i}, \lambda_{j t}$, and $B_{i}$ are the shadow prices associated with the constraints. The shadow price of each trader's compliance constraint, $\mu_{i}$ indicates the cost to society if the trader were given an additional $1 \mathrm{~kg} / \mathrm{ha} /$ year permit. We suggest that this price is correct, following theory of marginal cost pricing.

From the dual formulation of the above linear program, we can show that the individual participant price, $\mu_{i}=\sum_{j} \sum_{t} H_{i j t} \lambda_{j t}$, where $\lambda_{j t}$ is the market value of a unit increase in nitrate concentration, flux or mass at receptor $j$ in time period $t$. The above relationship indicates that the price of source $i$ is determined by its impacts on all the receptors over the planning horizon. From the dual formulation, we may also prove that the participant price, $\mu_{i}$ is at least the offer/reservation price or a better price if the bid/offer is selected. 


\section{Illustration}

In this section, we illustrate the proposed market with a simple case study. We assume a hypothetical groundwater catchment of $1 \times 2 \mathrm{~km}$ area, draining to a lake. Figure 1 shows a rough plan of the area. The catchment has six farms, each with five land use options. Table 1 shows the land use options and the expected nitrate leaching from each option. The regional authority wants to allocate nitrate permits among the farms to satisfy two environmental standards.

1. The mass nitrate input to the lake in every year is below the predetermined standard, 4 tonnes per year. Nitrate, once in the lake, does not reside there for more than a year.

2. The nitrate concentration of the drinking water well does not exceed $50 \mathrm{mg} / \mathrm{l}$ at any time.

The catchment has two receptors, the lake $(j=1)$ and the well $(j=2)$. Taking into account the two water quality standards and expected non-tradable source contributions including the nitrates already in the aquifer, the regional environmental authority has informed the market manager that in the current instance of trading, he should allocate only $1 / 8^{\text {th }}$ of the environmental standards. Hence, $S_{1 t}-C_{1 t}=5000 \mathrm{~kg}$ and $S_{2 t}-C_{2 t}=6.25 \mathrm{mg} / \mathrm{l}$ for all $t$, for this problem.

\subsection{A Trading System to Allocate Nitrate Permits}

Assume permits are valid for 5 years. The authority re-sets the initial allocations, calls for bids and offers, and clears the market every five years. The nitrate residence time in the catchment is approximately $40-50$ years and we consider a 40 year planning horizon. During this planning horizon, trading would occur and the market will be cleared eight times. We will discuss the results of the first instance of trading.

We simulated groundwater flow with MODFLOW and nitrate transport using MT3D. Some hydro-geological data used in the models are given in the appendix. Using the 
nitrate transport model, we simulated $1 \mathrm{~kg} / \mathrm{ha} /$ year nitrate leaching from each farm and obtained the transport coefficients $H_{i j t}$ shown in Table 2.

We assume that all non-point sources get the same initial allocation as a rate of loading in $\mathrm{kg} / \mathrm{ha} /$ year. We calculated the maximum feasible initial allocation from a simple linear program, which maximised initial allocation subject to water quality standards. The calculated initial allocation was $77.447 \mathrm{~kg} / \mathrm{ha} /$ year for every farm $\left(A_{i}=\right.$ 77.447 for all $i$ ). The binding water quality constraint which determined this initial allocation was the well concentration constraint for year 5: $0.0236 q_{1}+0 q_{2}+0.0398$ $q_{3}+0.0173 q_{4}+0 q_{5}+0 q_{6} \leq 6.25$. An initial allocation which binds a single constraint implies that only one constraint is fully allocated initially. We discuss the consequences of such initial allocation in the next section on outcomes of trade.

With this free initial allocation of permits, farms can adopt only options A or B1. If trade is allowed, farms can adopt other options. If a farm selects option A for the next 5 years, it can sell up to $9.447 \mathrm{~kg} / \mathrm{ha} /$ year of the permit. Similarly, if a farm selects option B1, it can sell up to $5.447 \mathrm{~kg} / \mathrm{ha} /$ year. If a farm wishes to adopt land use option B2, it has to buy at least $12.553 \mathrm{~kg} / \mathrm{ha} /$ year. Similarly, if any farm needs to adopt land use option C or D, it has to buy at least $24.553 \mathrm{~kg} / \mathrm{ha} /$ year or $54.553 \mathrm{~kg} / \mathrm{ha} /$ year respectively. Based on the initial allocation, the permit requirements, and profitability of land use options, the farms choose bids and offers which maximise their profits, each assuming that they cannot influence market price.

Our market design does not need to address the user's optimization problem. This trading system is not a decision support system for individual farmers, as farmers make their own production decisions given permit prices. However, to understand how the farmers will arrive at the bids/offers, assume that a farmer's potential five year profit from crop A, crop B, crop C, and livestock D are $\$ 5200, \$ 6400, \$ 6900$, and $\$ 7500$ respectively. Assume the best management practice for crop B costs $\$ 900$.

The graphs in Figure 2 show how this farmer's 5-year profit from each farming option would vary with the permit price. If the price is $\$ 20$ or less, option $D$ is most profitable. 
This farmer would buy $54.553 \mathrm{~kg} / \mathrm{ha} /$ year at $\$ 20 / \mathrm{kg} / \mathrm{ha} /$ year or at a lesser price. If the price is greater than $\$ 20$ but less than $\$ 41.67$, option $C$ is most profitable, and the farmer would buy $24.553 \mathrm{~kg} / \mathrm{ha} /$ year. If the price is above $\$ 41.67$ but below $\$ 50$, option B2 is most profitable and the farmer would buy $12.553 \mathrm{~kg} / \mathrm{ha} / \mathrm{year}$. If the price is over $\$ 50$ but below $\$ 75, \mathrm{~B} 1$ is the most profitable option and the farmer would sell $5.447 \mathrm{~kg} / \mathrm{ha} /$ year. If the price is over $\$ 75$, option $A$ is most profitable and the farmer would sell $9.447 \mathrm{~kg} / \mathrm{ha} /$ year.

In this trading system, every farm can submit up to five bids/offers. Based on those profit estimates, a rational farmer would bid as shown in Table 3. The estimated transport coefficients, initial allocations, other coefficients and bids/offers (assuming all farms bid/offer identically as shown in the last two columns of table 4) were substituted in the linear program discussed above. The market clearing linear program was solved with the above inputs to find the prices and allocations cleared. Table 4 shows the results generated by the linear program.

\subsection{Outcomes of Trade}

The results indicate that every farm is better off after trade. If trade is not allowed, all farms can grow only crop A or crop B which are least profitable. As a result of trading, farms 2 and 5 can farm livestock $D$ and crop $C$ which are most profitable. Farms 1 and 6 can save a large portion of the cost of best management practice by buying more permits. Farms 3 and 4 can make additional profit by farming crop A and crop B and selling the extra permits.

According to the results of trading listed in Table 4, buyers and sellers get at least their reservation price or better. Even though bids are identical, prices vary by location. The reason is that leaching at some locations has a greater impact on the binding constraints than leaching at other locations. The binding constraints were the well concentration constraint in year 5 , mass nitrate input constraint in year 6 , and mass nitrate input constraint in year 7, as listed in Table 5. Farm 3 has the highest price because it has the greatest impact on the well concentration in year $5(0.0398 \mathrm{mg} / \mathrm{l})$ 
which has the highest shadow price. Farm 2 has the lowest price because it has zero impact on the binding constraint with the highest shadow price and relatively small impacts on the others (1.04 kg and $1.97 \mathrm{~kg})$.

As the permits are defined on a per hectare basis, the prices depend on the farm size as well. Therefore, prices may not be comparable among the farms if the farm sizes (areas) vary significantly, which is not the case in this example (as shown in Figure 1, the areas of farms 1,3, 4, and 6 are equal to 30 ha while farms 2 and 6 are 32 ha and 28 ha respectively). In any case, comparable farm prices could be obtained by dividing the individual farm price by the area.

The total payment due to sellers is less than the total paid by buyers. As a result, the market manager gets a surplus of $\$ 1313.60$. This surplus is explained by the binding water quality constraints. The constraints for mass nitrate inputs in years 6 and 7 were not binding in the initial allocation (were not fully allocated initially), but becomes binding after trade (fully allocated after trade). These two constraints can be viewed as initially under-allocated resources where the market manger has kept aside 5000 $(0.29 \times 77.447+1.04 \times 77.447+3.87 \times 77.447+10.33 \times 77.447+17.09 \times 77.447+$ $22.71 \times 77.447)=714.56 \mathrm{~kg}$ of one resource and $5000-0.65 \times 77.447+1.97 \times 77.447+$ $6.04 \times 77.447+13.54 \times 77.447+15.41 \times 77.447+18.56 \times 77.447)=649.42 \mathrm{~kg}$ of the other. The buyers first buy from the market manger who sells his $714.56 \mathrm{~kg}$ of the first resource at the shadow price of the constraint, $\$ 1.52$ and his $649.42 \mathrm{~kg}$ of the other resource at the shadow price of the constraint, $\$ 0.35$. The surplus money left after clearing the market is the buyer's payment for the resources they bought from the market manager, $714.56 \times \$ 1.52+649.42 \times \$ 0.35=\$ 1313.00=$ surplus money left.

A surplus payment can be avoided if all the constraints were fully allocated by the initial distribution of permits. However, as Montgomery (1972) first pointed out, such an initial allocation of (emission) permits which binds all the constraints hardly exists, and that is the case with non-point source permits. 
Non-point source water pollution permits may be considered as a bundle of constraint rights where a constraint right is a right to increase the pollutant concentration, flux, or mass at a certain receptor in a certain time period (similar to ambient permits). Therefore, the permits may be broken up into constraint rights and each constraint may be fully allocated (independently without looking at other constraints) among the sources as an initial allocation (McGartland and Oates,1985). Then after the market is cleared, the individual payments/receipts should be calculated from the shadow prices of the constraints and the amounts of constraint rights purchased and sold.

The total bought, $109.493 \mathrm{~kg} / \mathrm{ha} /$ year, does not match the total sold, 11.606 $\mathrm{kg} / \mathrm{ha} / \mathrm{year}$, because the transport coefficients are different, and the permits are not comparable among farms. The quantities sold by farm 3 and farm 4 are 9.447 $\mathrm{kg} / \mathrm{ha} /$ year and $2.160 \mathrm{~kg} / \mathrm{ha} /$ year. These permits, if not sold, contribute to the well concentration in year 5 by $0.0398 \times 9.447+0.0173 \times 2.160=0.413 \mathrm{mg} / \mathrm{l}$. This equals the contribution of the 109.493 permits bought by farms $1,2,5$ and $6(0.0236 \times 17.515+$ $0 \times 54.553+0 \times 24.553+0 \times 12.871=0.413 \mathrm{mg} / \mathrm{l})$. The linear program rescales quantities so that the effects at the receptors remain feasible.

If farm 1 raised the price of his last three bids from $\$ 20, \$ 41$, and $\$ 49$ to $\$ 50$ each in order to buy more, then the result will be buying $19.926 \mathrm{~kg} / \mathrm{ha} / \mathrm{year}$, at $\$ 50$ each. The farmer will be penalized by a higher price. Even though farm 1 is prepared to pay more, it cannot buy more because it has a significant impact on the water quality constraints.

Potential profits with and without trade are calculated in Table 6. Every farm can make more profit if trade is allowed. Without trade, the potential profit for farmers is $\$ 33,000$. If trade is allowed, they can make a higher profit of $\$ 36,586$.

We simulated the nitrate loadings from the optimal permit allocation to verify that water quality standards were met in all periods. This verifying simulation may fail if the assumption of linearity were not true. 


\section{Discussion and Conclusions}

The proposed trading system is a breakthrough in pollution offset systems. Use of a linear program to clear the market is the dominant feature of this new pollution-offset type trading system. It overcomes limitations in conventional pollution offset systems, especially the high transaction costs.

The major criticism of pollution offset systems is that they have thin trading. A proposed pair-wise transaction may be infeasible because it violates quality standards. Even if simulation results allow a transaction, with one or two user-quantity changes at a time, the cost of the simulation itself raises the overall transaction cost considerably. By contrast, the proposed system facilitates multilateral trade. It provides higher potential for offsetting impacts from one user by adjusting quantities of multiple sellers simultaneously, and also avoids the need to simulate every user's transaction. The physical leaching and contaminant transport models determine coefficients for the linear program, which then chooses the optimal trades. Therefore, the use of physical models is one-off rather than for every transaction.

Because prices and allocations depend on the bids/offers and water quality constraints, this trading system should result in an economically optimal and environmentally feasible distribution of nitrate permits. Participants do not need to find trading partners because they buy from and sell to a common pool. They do not have to negotiate with affected parties, as the model manages impacts on all third parties and the environment. Information such as price history can be displayed freely on the trading system web. Therefore, the proposed trading system incurs almost no transaction costs. While we have demonstrated the system for nitrate, it is applicable for trading water pollution permits defined for any hydrological pollutant.

The outcomes of the proposed trading system depend on the accuracy of the transport coefficients. Market implementers should use well-calibrated hydrological models to determine these coefficients but, even if calibration is poor, our system would use existing data better than any other existing allocation system. The 
outcomes also rely on compliance to the land use practices allowed by the permits. Enforcement issues are beyond the scope of this paper.

Strategic behaviour may be possible and remains to be studied. In any case, whatever the offer price, whether users collude or attempt to game the system, water quality constraints still restrict the quantity bought (unless users break market rules outright). Therefore, strategic behaviour at worst would result in inefficient transfers between users. A user who wished to game the system (say, by buying all rights in the catchment in order to create a monopoly) would be heavily burdened by the local nature of the impacts, as determined by the transport coefficients.

The proposed trading system can attain efficient allocation of permits if the participants bid truthfully and do not behave strategically. Montero (2008) has presented an interesting work on mitigating strategic behaviours. He presented a modified sealed-bid auction for an endogenous number of permits including a system of paybacks or rebates to encourage the participants to bid truthfully. Montero's auction results in an efficient allocation of permits even if the participants collude and the total number of permits is fixed as in the case of water pollution permits. He has applied the auction to a water pollution problem in a river with five point sources, for a single period and single receptor. However, non-point sources have effects many periods into the future, and catchment managers may wish to consider multiple receptors. Therefore, Montero's system would need extensions to apply to the general non-point source water pollution problem.

An improved spatial and temporal trading system for NOx emissions is proposed in Martin, Joskow and Ellerman (2007). They demonstrated that a competitive electricity market could respond to emission prices. Emission prices would be determined by a cap and trade system for controlling NOx emissions into air. Trading ratios (exchange rates) can be varied by time and location based on weather and atmospheric forecasts. This is similar to our proposed nitrate trading system in that both consider zonal effects and depend on transport coefficients. However, pollutants in 
groundwater last longer than atmospheric pollution, so our system requires a much longer planning horizon.

We are extending this trading system to include both point and non-point sources. Other future work includes considering overland runoff, uncertainty aspects of the non-tradable source contributions, nutrient reducting land uses such as wetlands, and better methods of resource allocation over a very long planning horizon. Application of this trading system to a real agricultural catchment will help further evaluation of the system. 


\section{Appendix: Model parameters used with MODFLOW and MT3D simulations}

Horizontal hydraulic conductivity: $0.0006 \mathrm{~m} / \mathrm{s}$

Vertical hydraulic conductivity: $0.0003 \mathrm{~m} / \mathrm{s}$

Storage coefficient: $0.00011 / \mathrm{m}$

Porosity: 0.15

Recharge: $100 \mathrm{~mm} / \mathrm{year}$

Longitudinal dispersivity: $10 \mathrm{~m}$

Ratio, horizontal to longitudinal dispersivity: 0.1

Ratio, vertical to longitudinal dispersivity: 0.01

Distribution coefficient: $1^{*} 10^{-7} 1 /(\mathrm{mg} / \mathrm{l})$

Aquifer thickness: $20 \mathrm{~m}$

Model cell size: $100 m * 100 m * 20 m$ 


\section{References}

Coase, R. H. (1960). The Problem of Social Cost. Journal of Law and Economics, 3(1), 1-44.

Dales, J. H. (1968). Land, Water and Ownership. The Canadian Journal of Economics, 1(4), 791804.

Eheart, J. W., Brill, E. D., Lence, B. J., Kilgore, J. D., \& Uber, J. G. (1987). Cost Efficiency of TimeVarying Discharge Permit Programs for Water Quality Management. Water Resources Research, 23(2), 245-251.

Environment Waikato (2008). "Nitrate Contamination of Groundwater." Retrieved 26 December 2008, from http://www.ew.govt.nz/Environmental-

information/groundwater/Monitoring-groundwater-quality/Nitrate-contamination-ofgroundwater/

Ermoliev, Y., Michalevich, M., \& Nentjes, A. (2000). Markets for Tradable Emission and Ambient Permits: A Dynamic Approach. Environmental and Resource Economics, 15(1), 39-56.

Harbaugh, B. A. W., Banta, E. R., Hill, M. C., \& McDonald, M. G. (2000). MODFLOW-2000: The U.S. Geological Survey Modular Groundwater Model: U.S. Geological Survey.

Horan, R. D., Shortle, J. S., \& Abler, D. G. (2002). Point-Nonpoint Nutrient Trading in the Susquehanna River Basin. Water Resources Research, 38(5).

Hogan, W. W., Read, E. G., and Ring, B. J. (1996). Using mathematical programming for electricity spot pricing. International Transactions in Operations Research, 3, 243-253.

Hung, M. F., \& Shaw, D. (2005). A Trading-Ratio System for Trading Water Pollution Discharge Permits. Journal of Environmental Economics and Management, 49 (1), 83-102.

Kerr, S., Rutherford, K., \& Lock, K. (2007). Nutrient Trading in Lake Rotorua: Goals and Trading Caps: Motu Economic and Public Policy Research.

King, D. M., \& Kuch, P. J. (2003). Will Nutrient Credit Trading Ever Work? An Assessment of Supply and Demand Problems and Institutional Obstacles. Environmental Law Reporter: News and Analysis, 5-2003.

Krupnick, A.., Oates, W., \& Verg, E. V. D. (1983). On Marketable air Pollution Permits: The Case for a System of Pollution Offset. Journal of Environmental Economics and Management, 10, 233-247.

Leston, D. (1992). Simulation of a Two-Pollutant, Two-Season Pollution Offset System for the Colorado River of Texas below Austin. Water Resources Research, 28(5), 1311-1318.

Lock, K., \& Kerr, S. (2007). Nutrient Trading in Lake Rotorua: Where Are We Now: Motu Economic and Public Policy Research. 
Martin, K. C., Joskow, P. L., \& Ellerman, A. D. (2007). Time and Location Differentiated NOx Control in Competitive Electricity Markets Using Cap-and-Trade Mechanisms: Center for Energy and environmental Policy Research.

McGartland, A. (1988). A Comparison of Two Marketable Discharge Permit Systems. Journal of Environmental Economics and Management, 15, 35-44.

McGartlend, A. M., \& Oates, W. E. (1985). Marketable Permits for Prevention of Environmental Deterioration. Journal of environmental Economics and Management, 12, 207228.

Montero, J. P. (2008). A Simple Auction Mechanism for the Optimal Allocation of the Commons. American Economic Review, 98(1), 496-518.

Montgomery, W. D. (1972). Markets in Licenses and Efficient Pollution Control Programs. Journal of Economic Theory, 5(3), 395-418.

Morgan, C. L., Coggins, J. S., \& Eidman, V. R. (2000). Tradable Permits for Controlling Nitrates in Groundwater at the Farm Level: A Conceptual Model. Journal of Agricultural and applied Economics, 32(2), 249-258.

Morgan, D. S., \& Everett, R. (2005). Application of Simulation-Optimization Methods for Management of Nitrate Loading to Groundwater From Decentralized Wastewater Treatment Systems Near La Pine, Oregon: US Geological Survey Oregon Water Science Centre.

Neil, W. O., David, M., Moore, C., \& Joeres, E. (1983). Transferable Discharge Permits and Economic Efficiency: The Fox River. Journal of Environmental Economics and Management, 10(4), 346-355.

O'Shea, L. (2002). An Economic Approach to Reducing Water Pollution: Point and Diffuse Sources. The Science of the Total Environment, 282-283, 49-63.

Revenga, C., \& Mock, G. (2000). Dirty Water: Pollution Problems Persist: World Resources Institute.

U. S. Geological Survey. (1999). The Quality of Our Nation's Waters: Nutrients and Pesticides:

U. S. Geological Survey.

U. S. Geological Survey. (2006). Data Input Instructions for Groundwater Transport Process (GWT). Reston, Virginia.

Zheng, C. (1990). MT3D - A Modular Three-Dimensional Transport Model for Simulation of Advection, Dispersion and Chemical Reaction of Contaminants in Groundwater Systems. 


\section{Figure Legends}

Figure 1: A plan of the hypothetical catchment

Figure 2: Profitability of land use options vs. permit price. 
Tables

\begin{tabular}{|c|c|c|}
\hline Option & Description & Expected nitrate leaching \\
\hline A & Crop A & $68 \mathrm{~kg} / \mathrm{ha} /$ year \\
\hline B1 & Crop B with best management practice & $72 \mathrm{~kg} / \mathrm{ha} /$ year \\
\hline B2 & Crop B with conventional practice & $90 \mathrm{~kg} / \mathrm{ha} /$ year \\
\hline C & Crop C & 102 kg/ha/year \\
\hline D & Livestock D with 10 animals per hectare & $132 \mathrm{~kg} / \mathrm{ha} /$ year \\
\hline
\end{tabular}

Table 1: Land use options and expected nitrate leaching. 


\begin{tabular}{|c|c|c|c|c|c|c|c|c|c|c|c|c|}
\hline \multirow{2}{*}{$\begin{array}{r}\text { Year } \\
(t)\end{array}$} & \multicolumn{6}{|c|}{$j=1$ (nitrate input to the lake in $\mathrm{kg}$ ) } & \multicolumn{6}{|c|}{$j=2$ (concentration occurs in the well in $\mathrm{mg} / \mathrm{l}$ ) } \\
\hline & $i=1$ & $i=2$ & $i=3$ & $i=4$ & $i=5$ & $i=6$ & $i=1$ & $i=2$ & $i=3$ & $i=4$ & $i=5$ & $i=6$ \\
\hline 1 & 0.00 & 0.00 & 0.01 & 0.06 & 1.73 & 3.00 & 0.0005 & 0.0000 & 0.0074 & 0.0095 & 0.0000 & 0.0000 \\
\hline 2 & 0.00 & 0.01 & 0.07 & 0.46 & 5.31 & 8.78 & 0.0029 & 0.0000 & 0.0177 & 0.0137 & 0.0000 & 0.0000 \\
\hline 3 & 0.00 & 0.04 & 0.33 & 1.65 & 9.30 & 14.61 & 0.0078 & 0.0000 & 0.0271 & 0.0158 & 0.0000 & 0.0000 \\
\hline 4 & 0.03 & 0.16 & 0.97 & 3.81 & 13.01 & 19.45 & 0.0150 & 0.0000 & 0.0345 & 0.0168 & 0.0000 & 0.0000 \\
\hline 5 & 0.10 & 0.46 & 2.13 & 6.83 & 16.20 & 23.10 & 0.0236 & 0.0000 & 0.0398 & 0.0173 & 0.0000 & 0.0000 \\
\hline 6 & 0.29 & 1.04 & 3.87 & 10.33 & 17.09 & 22.71 & 0.0323 & 0.0001 & 0.0359 & 0.0082 & 0.0000 & 0.0000 \\
\hline 7 & 0.65 & 1.97 & 6.04 & 13.54 & 15.41 & 18.56 & 0.0389 & 0.0001 & 0.0281 & 0.0041 & 0.0000 & 0.0000 \\
\hline 8 & 1.28 & 3.28 & 8.39 & 15.79 & 12.86 & 13.82 & 0.0423 & 0.0001 & 0.0203 & 0.0021 & 0.0000 & 0.0000 \\
\hline 9 & 2.22 & 4.90 & 10.53 & 16.64 & 10.13 & 9.62 & 0.0423 & 0.0001 & 0.0139 & 0.0011 & 0.0000 & 0.0000 \\
\hline 10 & 3.47 & 6.69 & 12.13 & 16.13 & 7.61 & 6.36 & 0.0397 & 0.0001 & 0.0092 & 0.0006 & 0.0000 & 0.0000 \\
\hline 11 & 4.98 & 8.48 & 13.02 & 14.62 & 5.50 & 4.05 & 0.0353 & 0.0001 & 0.0060 & 0.0003 & 0.0000 & 0.0000 \\
\hline 12 & 6.56 & 10.00 & 13.05 & 12.43 & 3.82 & 2.49 & 0.0302 & 0.0001 & 0.0038 & 0.0002 & 0.0000 & 0.0000 \\
\hline 13 & 8.12 & 11.17 & 12.44 & 10.11 & 2.58 & 1.50 & 0.0248 & 0.0001 & 0.0024 & 0.0001 & 0.0000 & 0.0000 \\
\hline 14 & 9.48 & 11.93 & 11.35 & 7.90 & 1.70 & 0.89 & 0.0199 & 0.0001 & 0.0015 & 0.0001 & 0.0000 & 0.0000 \\
\hline 15 & 10.45 & 12.14 & 9.89 & 5.94 & 1.09 & 0.51 & 0.0155 & 0.0001 & 0.0009 & 0.0000 & 0.0000 & 0.0000 \\
\hline 16 & 11.01 & 11.94 & 8.34 & 4.34 & 0.68 & 0.29 & 0.0118 & 0.0001 & 0.0006 & 0.0000 & 0.0000 & 0.0000 \\
\hline 17 & 11.14 & 11.37 & 6.81 & 3.10 & 0.42 & 0.17 & 0.0088 & 0.0001 & 0.0004 & 0.0000 & 0.0000 & 0.0000 \\
\hline 18 & 10.85 & 10.52 & 5.41 & 2.16 & 0.26 & 0.09 & 0.0065 & 0.0000 & 0.0002 & 0.0000 & 0.0000 & 0.0000 \\
\hline 19 & 10.25 & 9.50 & 4.20 & 1.47 & 0.16 & 0.05 & 0.0047 & 0.0000 & 0.0001 & 0.0000 & 0.0000 & 0.0000 \\
\hline 20 & 9.35 & 8.33 & 3.18 & 0.98 & 0.09 & 0.03 & 0.0033 & 0.0000 & 0.0001 & 0.0000 & 0.0000 & 0.0000 \\
\hline 21 & 8.32 & 7.18 & 2.36 & 0.65 & 0.05 & 0.02 & 0.0024 & 0.0000 & 0.0000 & 0.0000 & 0.0000 & 0.0000 \\
\hline 22 & 7.22 & 6.05 & 1.72 & 0.42 & 0.03 & 0.01 & 0.0016 & 0.0000 & 0.0000 & 0.0000 & 0.0000 & 0.0000 \\
\hline 23 & 6.13 & 5.01 & 1.22 & 0.27 & 0.02 & 0.00 & 0.0011 & 0.0000 & 0.0000 & 0.0000 & 0.0000 & 0.0000 \\
\hline 24 & 5.09 & 4.08 & 0.86 & 0.17 & 0.01 & 0.00 & 0.0008 & 0.0000 & 0.0000 & 0.0000 & 0.0000 & 0.0000 \\
\hline 25 & 5.90 & 4.63 & 0.82 & 0.15 & 0.01 & 0.00 & 0.0005 & 0.0000 & 0.0000 & 0.0000 & 0.0000 & 0.0000 \\
\hline 26 & 1.58 & 1.22 & 0.19 & 0.03 & 0.00 & 0.00 & 0.0004 & 0.0000 & 0.0000 & 0.0000 & 0.0000 & 0.0000 \\
\hline 27 & 2.63 & 2.01 & 0.28 & 0.04 & 0.00 & 0.00 & 0.0002 & 0.0000 & 0.0000 & 0.0000 & 0.0000 & 0.0000 \\
\hline 28 & 2.04 & 1.55 & 0.18 & 0.03 & 0.00 & 0.00 & 0.0002 & 0.0000 & 0.0000 & 0.0000 & 0.0000 & 0.0000 \\
\hline 29 & 1.57 & 1.18 & 0.12 & 0.02 & 0.00 & 0.00 & 0.0001 & 0.0000 & 0.0000 & 0.0000 & 0.0000 & 0.0000 \\
\hline 30 & 1.19 & 0.88 & 0.08 & 0.01 & 0.00 & 0.00 & 0.0001 & 0.0000 & 0.0000 & 0.0000 & 0.0000 & 0.0000 \\
\hline 31 & 0.89 & 0.66 & 0.05 & 0.01 & 0.00 & 0.00 & 0.0000 & 0.0000 & 0.0000 & 0.0000 & 0.0000 & 0.0000 \\
\hline 32 & 0.66 & 0.48 & 0.03 & 0.00 & 0.00 & 0.00 & 0.0000 & 0.0000 & 0.0000 & 0.0000 & 0.0000 & 0.0000 \\
\hline 33 & 0.48 & 0.35 & 0.02 & 0.00 & 0.00 & 0.00 & 0.0000 & 0.0000 & 0.0000 & 0.0000 & 0.0000 & 0.0000 \\
\hline 34 & 0.35 & 0.26 & 0.01 & 0.00 & 0.00 & 0.00 & 0.0000 & 0.0000 & 0.0000 & 0.0000 & 0.0000 & 0.0000 \\
\hline 35 & 0.25 & 0.18 & 0.01 & 0.00 & 0.00 & 0.00 & 0.0000 & 0.0000 & 0.0000 & 0.0000 & 0.0000 & 0.0000 \\
\hline 36 & 0.18 & 0.13 & 0.01 & 0.00 & 0.00 & 0.00 & 0.0000 & 0.0000 & 0.0000 & 0.0000 & 0.0000 & 0.0000 \\
\hline 37 & 0.13 & 0.09 & 0.00 & 0.00 & 0.00 & 0.00 & 0.0000 & 0.0000 & 0.0000 & 0.0000 & 0.0000 & 0.0000 \\
\hline 38 & 0.09 & 0.06 & 0.00 & 0.00 & 0.00 & 0.00 & 0.0000 & 0.0000 & 0.0000 & 0.0000 & 0.0000 & 0.0000 \\
\hline 39 & 0.06 & 0.05 & 0.00 & 0.00 & 0.00 & 0.00 & 0.0000 & 0.0000 & 0.0000 & 0.0000 & 0.0000 & 0.0000 \\
\hline 40 & 0.04 & 0.03 & 0.00 & 0.00 & 0.00 & 0.00 & 0.0000 & 0.0000 & 0.0000 & 0.0000 & 0.0000 & 0.0000 \\
\hline
\end{tabular}


Table 2: Mass nitrate input to the lake $(\mathrm{kg})$ and concentration in the well $(\mathrm{mg} / \mathrm{l})$ that occurs due to $1 \mathrm{~kg} / \mathrm{ha} /$ year leaching from eac farm during the first 5 years(Transport Coefficients, $H_{i j t}$ for $j=1$ and $j=2$ ).

\begin{tabular}{|c|c|c|c|c|}
\hline \multirow[t]{2}{*}{ Permit price } & \multirow{2}{*}{$\begin{array}{r}\text { Most profitable } \\
\text { option }\end{array}$} & \multirow{2}{*}{$\begin{array}{r}\text { Extra permit required }(+) \\
\text { or available }(-)\end{array}$} & \multicolumn{2}{|c|}{ Bid/Offer } \\
\hline & & & Price & Quantity \\
\hline below $\$ 20.00$ & $\mathrm{D}$ & $54.553 \mathrm{~kg} / \mathrm{ha} /$ year & $\$ 20.00$ & $30.000 \mathrm{~kg} / \mathrm{ha} /$ year \\
\hline$\$ 20.00-\$ 41.66$ & C & $24.553 \mathrm{~kg} / \mathrm{ha} /$ year & $\$ 41.00$ & $12.000 \mathrm{~kg} / \mathrm{ha} /$ year \\
\hline$\$ 41.67-\$ 49.99$ & B2 & $12.553 \mathrm{~kg} / \mathrm{ha} /$ year & $\$ 49.00$ & $12.553 \mathrm{~kg} / \mathrm{ha} /$ year \\
\hline$\$ 50.00-\$ 74.99$ & B1 & $-5.447 \mathrm{~kg} / \mathrm{ha} /$ year & $\$ 50.00$ & $-5.447 \mathrm{~kg} / \mathrm{ha} /$ year \\
\hline above $\$ 75.00$ & $A$ & $-9.447 \mathrm{~kg} / \mathrm{ha} /$ year & $\$ 75.00$ & $-4.000 \mathrm{~kg} / \mathrm{ha} /$ year \\
\hline
\end{tabular}

Table 3: Submitted bids and offers.

\begin{tabular}{|r|r|r|r|r|r|}
\hline Source, $i$ & $\begin{array}{r}\text { Buy/sell, } b_{i} \\
\mathrm{~kg} / \mathrm{ha} / \mathrm{year}\end{array}$ & $\begin{array}{r}\text { Final qty, } q_{i} \\
\mathrm{~kg} / \mathrm{ha} / \mathrm{year}\end{array}$ & Price, $\mu_{i}$ & Payments & End land use \\
\hline Farm 1 & 17.516 & 94.963 & $\$ 41.00$ & $\$ 718.16$ & Crop B \\
Farm 2 & 54.553 & 132.000 & $\$ 2.27$ & $\$ 123.83$ & Livestock D \\
Farm 3 & -9.447 & 68.000 & $\$ 76.01$ & $-\$ 718.08$ & Crop A \\
Farm 4 & -2.160 & 75.287 & $\$ 50.00$ & $-\$ 107.98$ & Crop B with BMP \\
Farm 5 & 24.553 & 102.000 & $\$ 31.36$ & $\$ 769.96$ & Crop C \\
Farm 6 & 12.871. & 90.318 & $\$ 41.00$ & $\$ 527.71$ & Crop B \\
Total & & & & $\$ 1313.60$ & \\
\hline
\end{tabular}

Table 4: Permit allocations and prices determined by the linear program. 


\begin{tabular}{|l|l|r|}
\hline Binding constraint & Description & Shadow price \\
\hline $0.0236 q_{1}+0 q_{2}+0.0398 q_{3}+0.0173 q_{4}$ & Concentration in year 5 & \\
\hline $0 q_{5}+0 q_{6} \leq 6.25$ & & \\
\hline $0.29 q_{1}+1.04 q_{2}+3.87 q_{3}+10.33 q_{4}+$ & Mass input in year 6 & \\
$17.09 q_{5}+22.71 q_{6} \leq 5000$ & & \\
$0.65 q_{1}+1.97 q_{2}+6.04 q_{3}+13.54 q_{4}+$ & Concentration in year 7 & \\
$15.41 q_{5}+18.56 q_{6} \leq 5000$ & & \\
\hline
\end{tabular}

Table 5: Binding constraints in the linear programming solution.

\begin{tabular}{|r|r|r|r|r|r|r|}
\hline \multirow{2}{*}{ Farm } & \multicolumn{3}{|c|}{ Without trading } & \multicolumn{3}{c|}{ Trading allowed by the proposed trading system } \\
\cline { 2 - 7 } & Land use & Profit & Land use & Profit from & Profit from & Net profit \\
\hline 1 & Crop B & $\$ 5,500$ & Crop B & $\$ 6400$ & $-\$ 718.16$ & $\$ 5681.84$ \\
2 & Crop B & $\$ 5,500$ & Livestock D & $\$ 7500$ & $-\$ 123.83$ & $\$ 7376.17$ \\
3 & Crop B & $\$ 5,500$ & Crop A & $\$ 5200$ & $\$ 718.08$ & $\$ 5918.08$ \\
4 & Crop B & $\$ 5,500$ & Crop B & $\$ 5500$ & $\$ 107.98$ & $\$ 5607.98$ \\
5 & Crop B & $\$ 5,500$ & Crop C & $\$ 6900$ & $-\$ 769.96$ & $\$ 6130.04$ \\
6 & Crop B & $\$ 5,500$ & Crop B & $\$ 6400$ & $-\$ 527.71$ & $\$ 5872.29$ \\
& Total & $\$ 33,000$ & & & & $\$ 36,586.40$ \\
\hline
\end{tabular}

Table 6: Potential gains from trade. 